\title{
Particulate fraction in amniotic fluid at second trimester
}

\author{
H JALANKO, $†$ J RAPOLA, $\ddagger$ E LEHTONEN* \\ From the †Departments of Bacteriology, Immunology, and ${ }^{*}$ Pathology, the University of Helsinki and the \\ ‡Children's Hospital, University Central Hospital, Helsinki, Finland.
}

SUMmary Amniotic fluid at 15-20 weeks contains high concentrations of microvillar enzymes which serve as markers for the prenatal diagnosis of cystic fibrosis. We found that these enzymes were mostly bound to amniotic fluid particulate fraction which eluted in the void volume on Sepharose 6B chromatography and precipitated in ultracentrifugation at $100,000 \mathrm{~g}$. Electron microscopy showed that the particulate fraction comprised membrane fragments and small vesicles. It represented less than $1 \%$ of the total protein in cell free amniotic fluid. Sorbitol gradient centrifugation showed heterogeneity in the particulate fraction. The enzyme patterns of amniotic fluid and meconium particulate fractions resembled each other. Antiserum against particulate fraction in amniotic fluid strongly reacted with early meconium and fetal small intestine in immunodiffusion, enzyme immunoassay, and staining with immunoperoxidase. The results suggest that most of the enzyme rich particulate fraction in early amniotic fluid originates in the fetal intestine.

Early human amniotic fluid contains considerable amounts of microvillar enzyme activity: $\boldsymbol{\gamma}$-glutamyl transpeptidase; leucine aminopeptidase; disaccharidases; and alkaline phosphatase..$^{1^{-4}}$ These enzymes have recently provoked clinical interest as exceptionally low concentrations of microvillar enzyme activities have been found in pregnancies complicated by fetal trisomy 18 syndrome ${ }^{56}$ and cystic fibrosis ${ }^{7-9}$ Measurement of phenylalanine sensitive and homoarginine sensitive variants of alkaline phosphatase shows considerable promise for the early prenatal diagnosis of cystic fibrosis. ${ }^{10}$

Studies by gel filtration and ultracentrifugation show that $\gamma$-glutamyl transpeptidase is present in amniotic fluid in a high molecular weight form. ${ }^{11} 12$ Treatment of amniotic fluid with a detergent or papain solubilises the enzyme, suggesting that it is bound to membrane particles. This finding prompted us to characterise the high molecular weight material of the amniotic fluid at second trimester and to study whether the other microvillar enzymes were also bound to this fraction. The origin of this material was studied by comparing the patterns of enzyme activity in different fetal tissues and amniotic fluid. We also prepared an antiserum against the particulate fraction in amniotic fluid and studied the

Accepted for publication 8 May 1985 reactivity of this antiserum with fetal tissues and body fluids.

\section{Material and methods}

\section{MATERIAL}

Samples of amniotic fluid were originally collected by amniocentesis for measurements of $\alpha$ fetoprotein. Specimens of fetal tissue and body fluids came from pregnancies undergoing elective termination between 15 and 19 weeks.

Chemicals for the enzyme assays were purchased from Sigma Chemical Company (St Louis, United States). Freund's complete adjuvant came from Difco Laboratories (Detroit, United States) and peroxidase conjugated antirabbit immunoglubulin was obtained from Dako-Patts (Copenhagen, Denmark). Sepharose 6B and molecular weight markers for gel filtration and sodium dodecyl sulphate gel electrophoresis came from Pharmacia Fine Chemicals (Uppsala, Sweden). All other reagents were of analytical grade and were obtained from different commercial sources.

\section{ENZYME ASSAYS AND PROTEIN}

DETERMINATIONS

$\gamma$-glutamyl transpeptidase and leucine aminopeptidase were measured using $\gamma$-glutamyl-p-nitroanilide and leucine-p-nitroanilide as substrates, respec- 
tively. ${ }^{1314}$ Sucrase and trehalase activities were measured according to the method of Dahlqvist. ${ }^{15}$ Total alkaline phosphatase activity and the phenylalanine and homoarginine sensitive alkaline phosphatase variants were determined as described by Brock $e t$ al. ${ }^{10}$ Protein was assayed according to the method of Lowry et $a^{16}$ or by Biorad protein assay (Bio-Rad Laboratories, Richmond, California).

\section{GEL FILTRATION}

Gel filtration was performed on a Sephrarose 6B column (bed volume $136 \mathrm{ml}$ ) in $0 \cdot 1 \mathrm{M}$ phosphate buffer, pH 7.6. Thyroglobulin (669 000), catalase (232 000), and albumin (67 000) were used as markers of molecular weight.

\section{CENTRIFUGATION}

Particulate fraction of amniotic fluid was isolated so that cell free samples were first centrifuged at $10000 \mathrm{~g}$ for 15 minutes. The supernatant was then recentrifuged at $100000 \mathrm{~g}$ for 65 minutes at $4^{\circ} \mathrm{C}$ (Beckman L3-50 centrifuged). The precipitate was washed with $0 \cdot 1 \mathrm{M}$ phosphate buffer, $\mathrm{pH} 7 \cdot 6$, and after centrifugation at $100000 \mathrm{~g}$ the pellet was suspended in the phosphate buffer and protein determined. Differential centrifugations of samples of fresh amniotic fluid were performed as indicated in Fig. 2. Density gradient centrifugation in 5-50\% sorbitol gradient was performed according to the method of Mircheff and Wright. ${ }^{17}$

The particulate material from meconium and fetal tissues was prepared, so that the specimens were first homogenised in ice cold phosphate buffer with Teflon homogeniser ${ }^{18}$ and the homogenates were then centrifuged in the same way as for the particulate fraction in amniotic fluid.

\section{SODIUM DODECYL SULPHATE GEL \\ ELECTROPHORESIS}

Disc electrophoresis in the presence of sodium dodecyl sulphate was performed in $7 \%$ polyacrylamine slab gels. The protein bands were stained with comassie brilliant blue. For the immunoprecipitation experiment, the gels were dried and subjected to autoradiography.

\section{ANTISERA}

Antisera against particulate fractions from amniotic fluid and meconium were induced by immunising rabbits with four injections of the corresponding particulate fractions $(0.5 \mathrm{mg}$ protein) in Freund's complete adjuvant.

IMMUNODIFFUSION

A double immunodiffusion was performed in $1 \%$ agar containing $0.5 \%$ triton $\mathrm{X}-100$. The whole tissue homogenates were dissolved in phosphate buffered saline containing $1 \%$ triton X-100 (final protein concentration $2 \mathrm{mg} / \mathrm{ml}$ ).

\section{IMMUNOPRECIPITATION}

The particulate fraction in amniotic fluid iodinated in phosphate buffered saline containing $1 \%$ triton $\mathrm{X}-100$. Ten $\mu \mathrm{l}$ of the iodinated particulate fraction solution $\left(3 \times 10^{6} \mathrm{cpm}\right)$ was first incubated with $10 \mu \mathrm{l}$ of normal rabbit serum and $100 \mu \mathrm{l}$ of protein A-sepharose (1/2 dilution). After centrifugation the supernatant was incubated with $10 \mu$ l of antisera against particulate fraction from amniotic fluid, antisera against particulate fraction from meconium, or normal rabbit serum. The immunoglobulins were
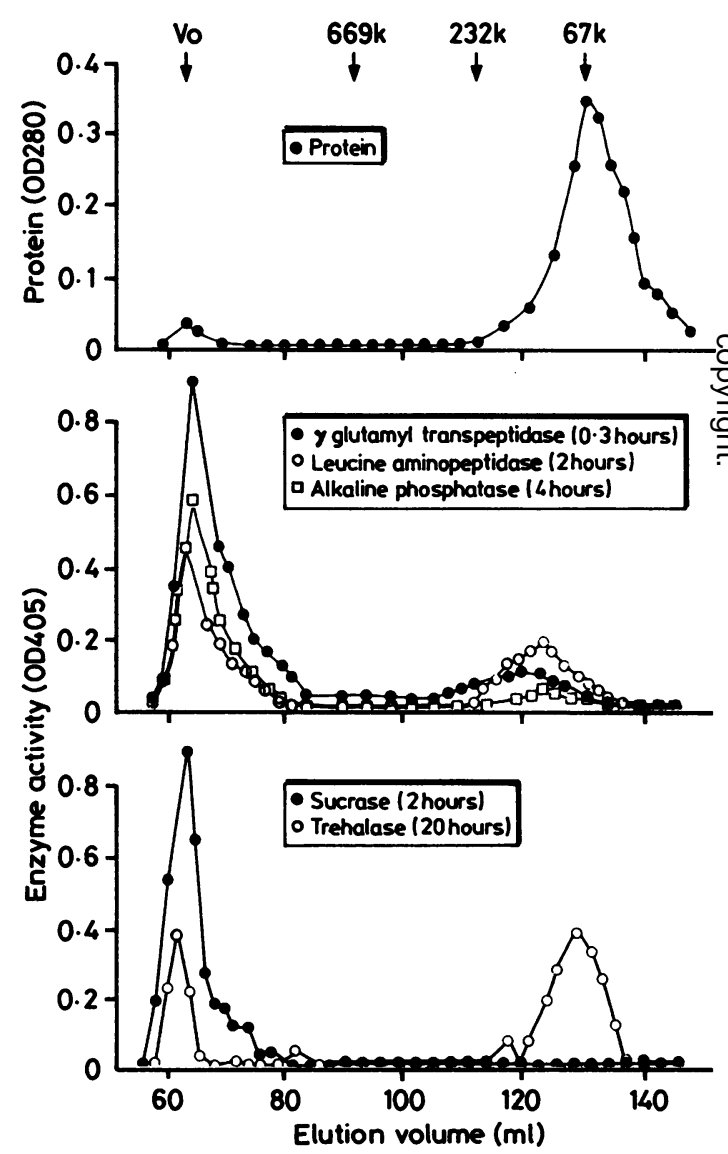

Fig. 1 Gel chromatography on Sepharose $6 B$ of amniotic fuid at sixteen weeks. Time of incubation for the enzyme assays of fractions is given in parentheses. Phenylalanine sensitive alkaline phosphatase and homoarginine sensitive alkaline phosphatase gave profiles similar as to total alkaline phosphatase. 
again precipitated by protein A-sepharose and the precipitates were thereafter subjected to sodium dodecyl sulphate-gel electrophoresis and autoradiography. ${ }^{19}$

\section{ENZYME IMMUNOASSAY}

Flat bottomed polystyrene microtiter plates (Flow Laboratories) were coated with $200 \mu$ l of particulate fraction in amniotic fluid in $0.05 \mathrm{M}$ carbonate buffer, $\mathrm{pH} 9.5$. The final protein concentration was $10 \mu \mathrm{g} / \mathrm{ml}$. After overnight incubation the plates were washed with phosphate buffered saline containing $0.5 \%$ (vol/vol) Tween 20 (polyoxyethylene sorbitan monolaureate; phosphate buffered salineTween). Various dilutions (1/100-1/1 024 000) of antiserum in phosphate buffered saline-Tween supplemented with $0.1 \%$ normal rabbit serum or $2 \%$ normal human serum were then added for 16 hours. After repeated washes with phosphate buffered saline-Tween the wells were incubated for two hours with peroxidase labelled antirabbit immunoglobulin $(1 / 400)$ in phosphate buffered saline-Tween containing $1 \%$ bovine serum albumnin. The plates were then washed and the enzyme reaction was carried out using o-phenylenediamine $(0.4 \mu \mathrm{g} / \mathrm{ml})$ in $0.1 \mathrm{M}$ phosphate citrate buffer, $\mathrm{pH} 5 \cdot 5$, as a substrate. The reaction was terminated by $2 \mathrm{M} \mathrm{H}_{2} \mathrm{SO}_{4}$ and the

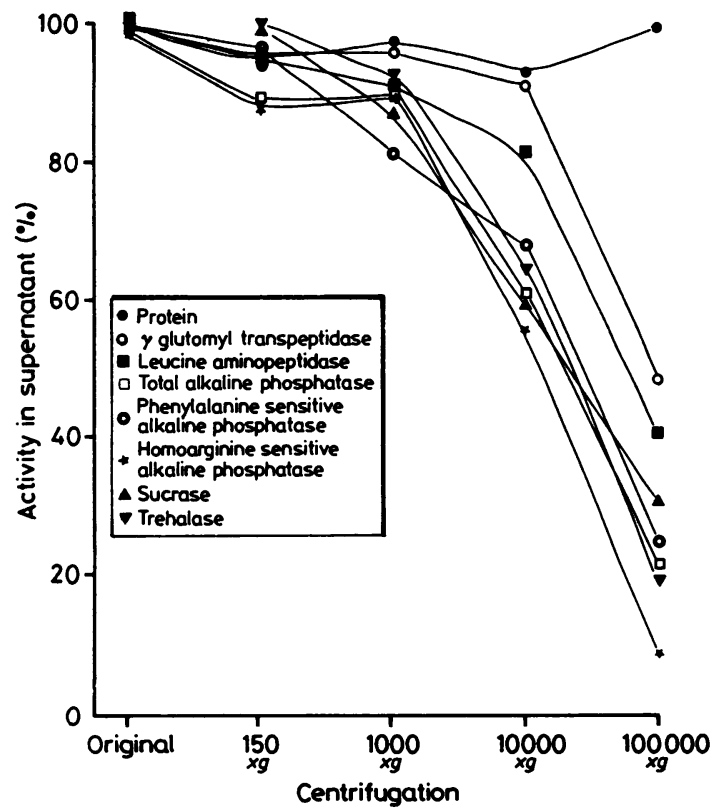

Fig. 2 Differential centrifugation of amniotic fuid at second trimester. Time for centrifugation was 60 minutes in ultracentrifugation $(100,000 \mathrm{~g})$ and 15 minutes in other centrifugations. Each point represents mean of all five experiments. absorbance at $492 \mathrm{~nm}$ was recorded using a vertical pathway spectrophotometer (Titertek-Multiskan, Helsinki, Finland).

In the inhibition assays the fetal tissue homogenates and body fluids were first diluted into phosphate buffered saline-Tween containing $2 \%$ normal human serum and $1 \mathrm{mM}$ phenylmethyl sulphonyl fluoride as a protease inhibitor. One hundred $\mu$ l of the solutions and $100 \mu \mathrm{l}$ of antiserum against particulate fraction from amniotic fluid (final dilution $1 / 80,000$ ) were then applied on the wells coated with the particulate fraction in amniotic fluid. The assay was thereafter performed as previously described. The results were expressed as percentages of the absorbance obtained with the inhibitor as compared with the absorbance without inhibitor. In control experiments the first or second antibodies, or both, were replaced by normal rabbit serum or buffers.
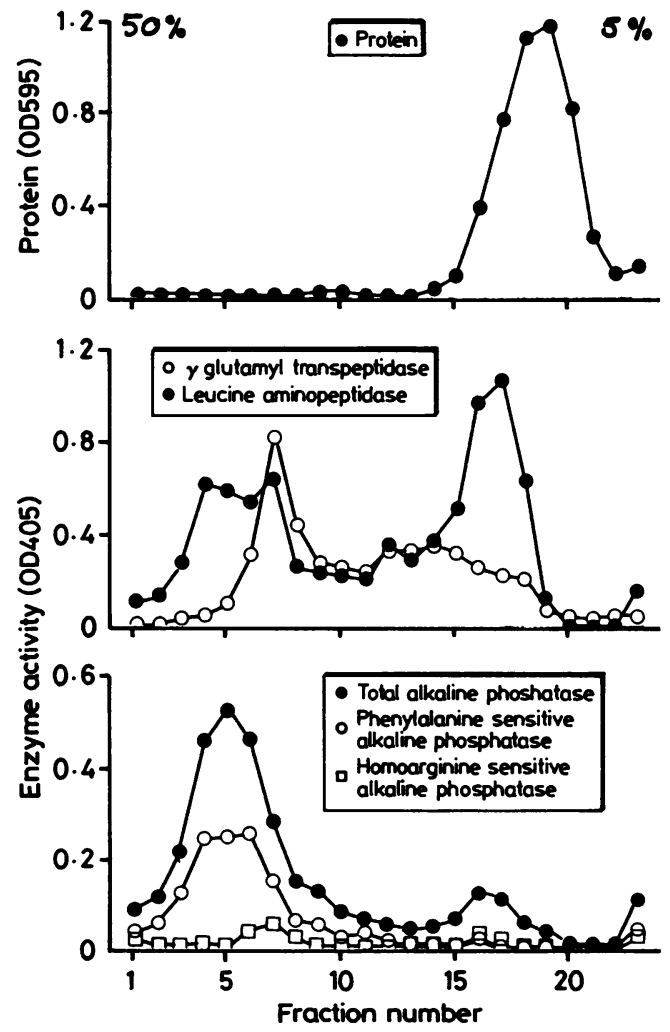

Fig. 3 Sorbitol gradient centrifugation of second trimester amniotic fuid. Incubation times for enzyme assays were: 66T 15 minutes; LAP 110 minutes and ALP 130 minutes. 
Table 1 Specific enzyme activities (nmol/min/mg protein) in early cell free amniotic fuid and in precipitate of ultracentrifugation at $100,000 \mathrm{~g}$ (60 minutes)

\begin{tabular}{|c|c|c|c|c|c|c|c|}
\hline & $\begin{array}{l}\gamma \text {-glutamyl } \\
\text { transpeptidase }\end{array}$ & $\begin{array}{l}\text { Leucine } \\
\text { aminopeptidase }\end{array}$ & $\begin{array}{l}\text { Alkaline } \\
\text { phosphatasetota }\end{array}$ & $\begin{array}{l}\text { Alkaline } \\
\text { phosphatase } \\
\text { phenylalanine } \\
\text { sensitive }\end{array}$ & $\begin{array}{l}\text { Alkaline } \\
\text { phosphatase } \\
\text { homoarginine } \\
\text { sensitive }\end{array}$ & Sucrase & Trehalase \\
\hline $\begin{array}{l}\text { Original amniotic fluid } \\
\text { Particulate fraction }\end{array}$ & $\begin{array}{l}103^{*} \\
(80-130) \\
1007 \\
(848-1207)\end{array}$ & $\begin{array}{l}21 \\
(16-27) \\
885 \\
(830-980)\end{array}$ & $\begin{array}{l}16 \\
(13-23) \\
895 \\
(708-1068)\end{array}$ & $\begin{array}{l}6 \cdot 7 \\
(4 \cdot 2-9 \cdot 8) \\
501 \\
(369-616)\end{array}$ & $\begin{array}{l}2 \cdot 8 \\
(2 \cdot 3-3 \cdot 7) \\
35 \\
(1 \cdot 0-74)\end{array}$ & $\begin{array}{l}7 \cdot 5 \\
(6 \cdot 1-10) \\
642 \\
(560-780)\end{array}$ & $\begin{array}{l}0.7 \\
(0.6-0.9) \\
34 \\
(25-48)\end{array}$ \\
\hline
\end{tabular}

*Mean of three separate experiments (range).

\section{ELECTRON MICROSCOPY AND}

IMMUNOPEROXIDASE STAINING

The indirect staining with immunoperoxidase on fetal tissues fixed in formalin and embedded in paraffin and the electron microscopy of the particulate fraction in amniotic fluid were performed according to standard methods. ${ }^{20}$

\section{Results}

\section{MICROVILLAR ENZYMES ACTIVITIES IN}

AMNIOTIC FLUID

Over $90 \%$ of the enzymatic activities of $\gamma$-glutamyl transpeptidase, leucine aminopeptidase, alkaline phosphate, and sucrase, as well as half of the trahalase activity, eluted in the void volume on Sepharose 6B chromatography (Fig. 1). On differential centrifugation of amniotic fluid most of the microvillar enzyme activities were present in the supernatant after centrifugation at $100000 \mathrm{~g}$ for 60 minutes (Fig. 2). Heterogeneity in the distribution of the enzyme activities was seen on density gradient centrifugation of samples of fresh amniotic fluid (Fig. 3).
The peak of total alkaline phosphatase and phenylalanine sensitive alkaline phosphatase activity was present in higher sorbitol density (fraction 5) than that of $\gamma$-glutamyl transpeptidase and homoarginine sensitive alkaline phosphatase (fraction 7). Leucine aminopeptidase showed a bimodial distribution with a wide high density peak (fractions 4-7) and a significant low density peak (fractions 16-17). On density gradient centrifugation of samples of dialysed amniotic fluid, with endogenic sugars removed, the peak of disaccharidase activity coeluted with the alkaline phosphatase peak.

PROPERTIES OF THE PARTICULATE FRACTION IN AMNIOTIC FLUID

When the supernatant from centrifugation $10000 \mathrm{~g}$ was subjected to ultracentrifugation $100000 \mathrm{~g}$ a pellet was obtained (amniotic fluid PF) which was rich in microvillar enzymes. The specific enzyme activities in particulate fraction were 10 to 86-fold higher than in the original amniotic fluid (Table 1). Particulate fraction in amniotic fluid was mainly composed of unorganised membrane fragments and vesicles, as studied by light and electron

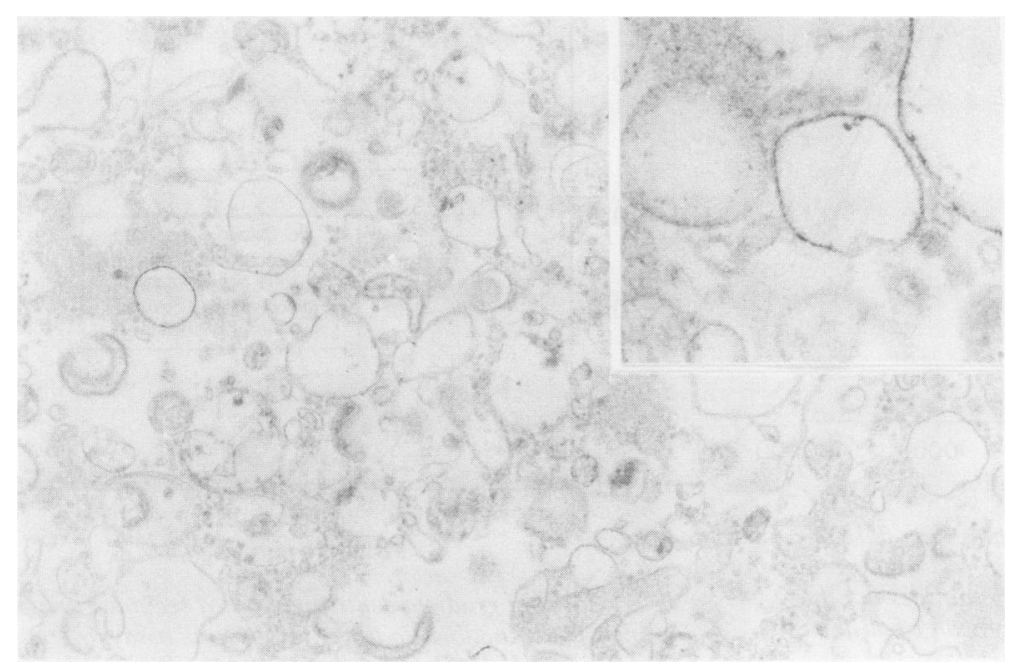

Fig. 4 Electron micrographs of particulate fraction in amniotic fuid showing unorganised membrane fragments and small vesicles (inset). Original magnifications $20,000 \times$ inset $40,000 \times$. 


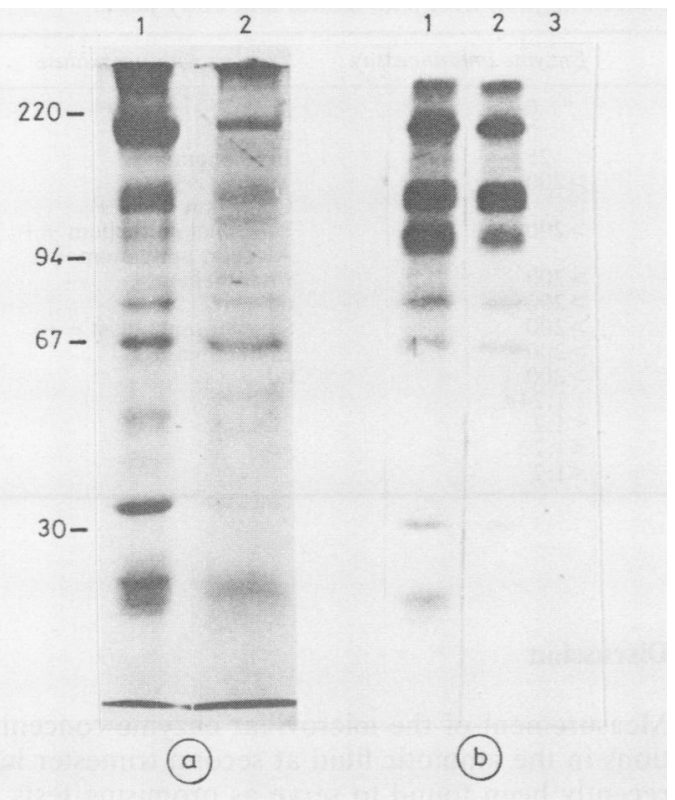

Fig. 5 (a): sodium dodecyl sulphate-gel electrophoresis of particulate fraction in amniotic fuid (1) particulate fraction in meconoium (2) (b): sodium dodecyl sulphate-gel electrophoresis followed by autoradiography of immunoprecipitates of radiolabelled particulate fraction from amniotic fuid (1), antisera against particulate fraction from amniotic fuid (2), antisera against particulate fraction from meconium (3), normal rabbit serum.

microscopy (Fig. 4). Particulate fraction from $1 \mathrm{ml}$ of amniotic fluid contained $15-21 \mu \mathrm{g}$ of protein accounting for $0 \cdot 2-0.4 \%$ of the total protein in cell free amniotic fluid. Over 20 polypeptide bands were easily seen on sodium dodecyl sulphate-gel electrophoresis of the particulate fraction in amniotic fluid (Fig. 5). This pattern was constant in five different preparations of particulate fraction in amniotic fluid.
ORIGIN OF THE PARTICULATE FRACTION IN

AMNIOTIC FLUID: ENZYMATIC STUDIES

Particulate material from several fetal tissues and meconium were prepared and the specific enzyme activities in these preparations and particulate fraction in amniotic fluid were compared. As shown in Table 2, the patterns of activity in meconium and the small bowel most closely resembled the pattern observed in the particulate fraction in amniotic fluid. The best marker in this respect was sucrase, the activity of which in other samples was less than $1 \%$ of that found in particulate fraction in amniotic fluid. The patterns of protein in amniotic fluid and particulate fraction in meconium were also similar on sodium dodecyl sulphate-gel electrophoresis (Fig. 5).

\section{ORIGIN OF THE PARTICULATE FRACTION IN}

AMNIOTIC FLUID: IMMULOGICAL STUDIES

Antiserum raised against amniotic fluid particulate fraction was polyvalent as shown by its capacity to precipitate several polypeptide bands from radiolabelled particulate fraction in amniotic fluid (Fig. 5). The antiserum reacted in immunodiffusion with homogenates of meconium and small bowel and, to a lesser extent, with that of kidney but not with other tissues or body fluids, such as normal human serum, fetal serum, or newborn urine (Table 3 ). Antisera against particulate fraction from amniotic fluid and antisera against particulate fraction from meconium antisera showed similar strong reactivity with the particulate fraction in amniotic fluid in enzyme immunoassay (Fig. 6). The binding of antisera against particulate fraction from amniotic fluid could, effectively be inhibited by extracts of meconium and small bowel (Fig. 7). An inhibition of $50 \%$ was obtained with particulate fractions from early amniotic fluid and meconium with $0.3 \mu \mathrm{g}$ and $0.8 \mu \mathrm{g}$ of protein, respectively (Table 3 ). Extract of kidney also showed inhibition in enzyme immunoassay but other tissues were inhibitory in only very

Table 2 Comparison of the specific enzyme activities of particulate fraction of amniotic fuid and particulate fractions from different fetal tissues and cultured amniotic fuid cells.

\begin{tabular}{|c|c|c|c|c|c|c|c|c|c|c|}
\hline & $\begin{array}{l}\text { Amniotic } \\
\text { fuid }\end{array}$ & Meconium & Intestines & Kidney & Lung & Liver & Skin & Placenta & $\begin{array}{l}\text { Amniotic } \\
\text { membrane }\end{array}$ & $\begin{array}{l}\text { Amniotic } \\
\text { fuid cells }\end{array}$ \\
\hline \multicolumn{11}{|l|}{$\gamma$-glutamyl } \\
\hline transpeptidase & $1 \cdot 00$ & $1 \cdot 67$ & $0 \cdot 23$ & 0.86 & 0.23 & 0.33 & $0 \cdot 10$ & 0.04 & 0.89 & $0 \cdot 13$ \\
\hline Leucine aminopeptidase & $1 \cdot 00$ & $1 \cdot 33$ & $0 \cdot 27$ & 0.27 & 0.06 & 0.08 & 0.07 & $0 \cdot 10$ & $0 \cdot 17$ & 0.07 \\
\hline $\begin{array}{l}\text { Akaline phosphatase-tot } \\
\text { Alkaline phosphatase }\end{array}$ & $1 \cdot 00$ & $3 \cdot 32$ & $4 \cdot 38$ & $5 \cdot 25$ & 0.45 & $3 \cdot 25$ & 0.98 & & $1 \cdot 02$ & $1 \cdot 35$ \\
\hline phenylaline sensitive & $1 \cdot 00$ & $3 \cdot 82$ & $2 \cdot 41$ & 1.43 & 0.04 & 0.09 & 0.43 & 0.14 & 0.35 & $1 \cdot 33$ \\
\hline $\begin{array}{l}\text { Alkalne pnospnatase } \\
\text { homoarginine sensitive }\end{array}$ & 1.00 & 3.07 & 1.66 & $72 \cdot 4$ & $7 \cdot 75$ & 52.4 & $12 \cdot 8$ & $7 \cdot 70$ & $12 \cdot 3$ & 5.44 \\
\hline Sucrase & $1 \cdot 00$ & 0.94 & 0.17 & $<0.01$ & $<0.01$ & $<0.01$ & $<0.01$ & $<0.01$ & $<0.01$ & $<0.01$ \\
\hline Trehalase & 1.00 & 0.68 & 0.35 & 0.20 & 0.03 & $<0.01$ & 0.05 & 0.03 & 0.02 & 0.03 \\
\hline
\end{tabular}


Table 3 Reactivity of antisera against particulate fraction from amniotic fuid with fetal tissues and body fuids

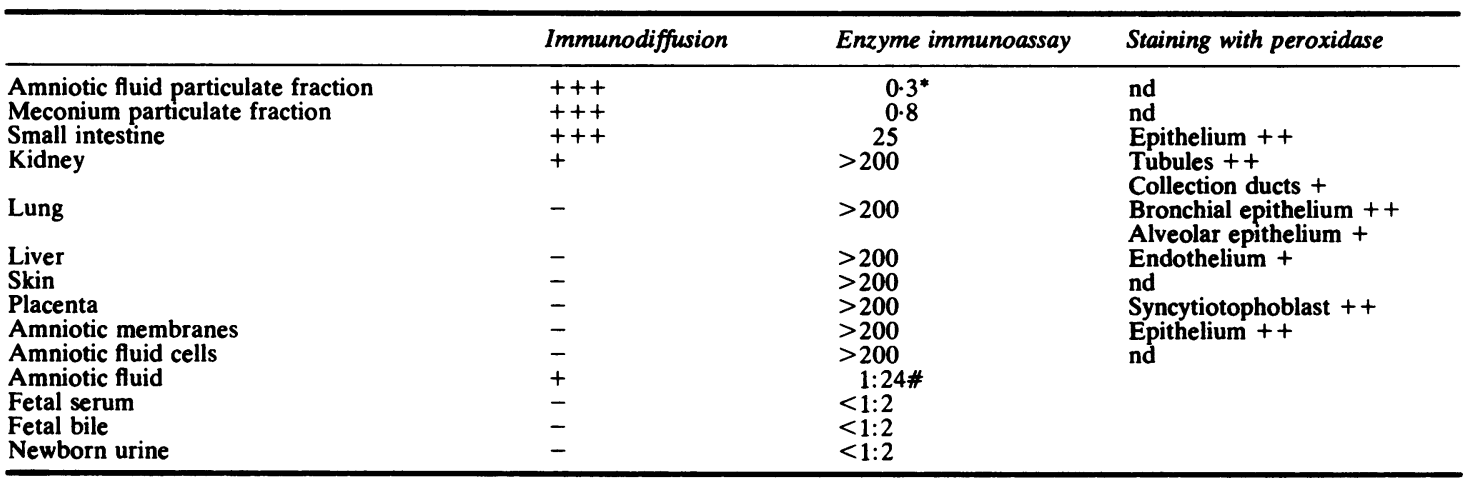

* $\mu$ g of protein giving $50 \%$ inhibition.

\#dilution giving $50 \%$ inhibitioin.

nd $=$ not done.

high protein concentrations (Fig. 7).

Positive immunoperoxidase staining with antisera against particulate fraction from amniotic fluid was obtained with several fetal tissues, as summarised in Table 3 and Fig. 8.

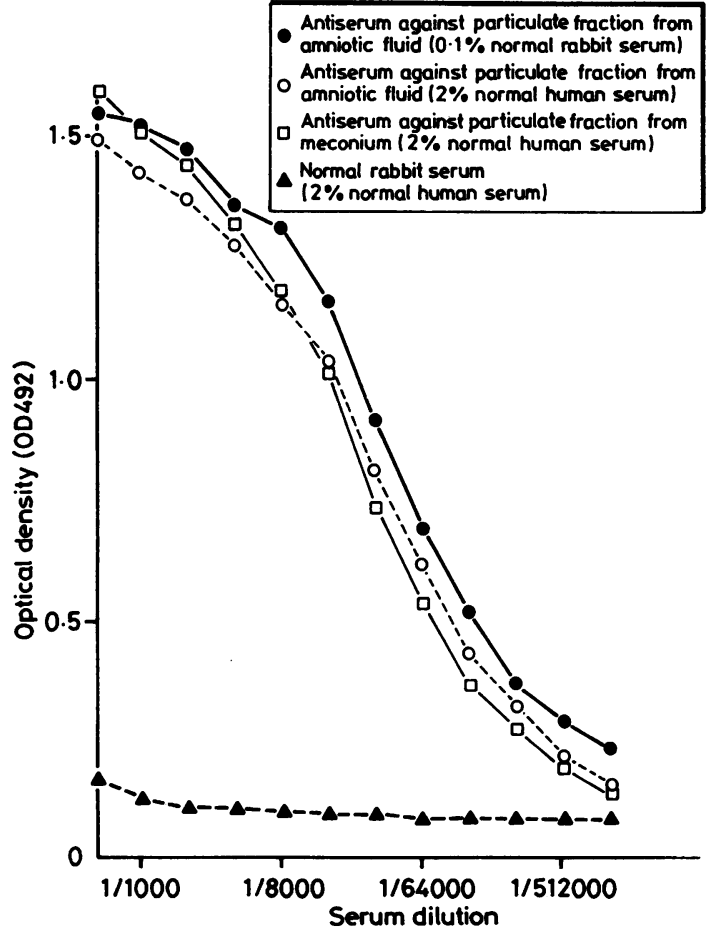

Fig. 6 Binding of antisera against particulate fraction from amniotic fuid and antisera against particulate fraction from meconium to particulate fraction in amniotic fuid in enzyme immunoassay. The sera were diluted into phosphate buffered saline-Tween containing either $0.1 \%$ normal rabbit serum or $2 \%$ normal human serum.

\section{Discussion}

Measurement of the microvillar enzyme concentrations in the amniotic fluid at second trimester have recently been found to serve as promising tests for the prenatal diagnosis of cystic fibrosis. ${ }^{7-10}$ In this study we investigated the physiochemical basis of these measurements and found that the microvillar enzymes were present in the amniotic fluid, not as soluble proteins, but as components of high molecular weight particular material. This particulate fraction rich in enzymes represented less than $1 \%$ of the total amniotic fluid protein and was precipitated by centrifugation at $100000 \mathrm{~g}$. Density-gradientcentrifugation-showed heterogeneity in this material tract.

Salafsky and Nadler performed differential centrifugation on amniotic fluid at second trimester and studied the resulting pellets by electron microscopy. ${ }^{21}$ They found that the $600 \mathrm{~g}$ pellet contained mitochondria, the $4,200 \mathrm{~g}$ pellet contained lysosomes, and the $30000 \mathrm{~g}$ and $60000 \mathrm{~g}$ pellets contained small vesicles and elements of endoplasmic reticulum. They also found that over $85 \%$ of the recovered alkaline phosphatase and $\alpha-1,4-$ glycosidase activities were localised in the pellets. From these findings they concluded that the amniotic fluid at second trimester contained various intracellular organelles in addition to intact amniotic fluid cells. We performed electron microscopy on the fraction that was soluble at $10000 \mathrm{~g}$ but precipitated out at 100000 , and found that this material comprised unorganised membrane fragments and vesicles. This confirms the findings of Salafsky and Nadler. ${ }^{21}$ This material, however, was extremely rich in microvillar enzymes, suggesting that it represents fragments of epithelial cell plasma membranes 


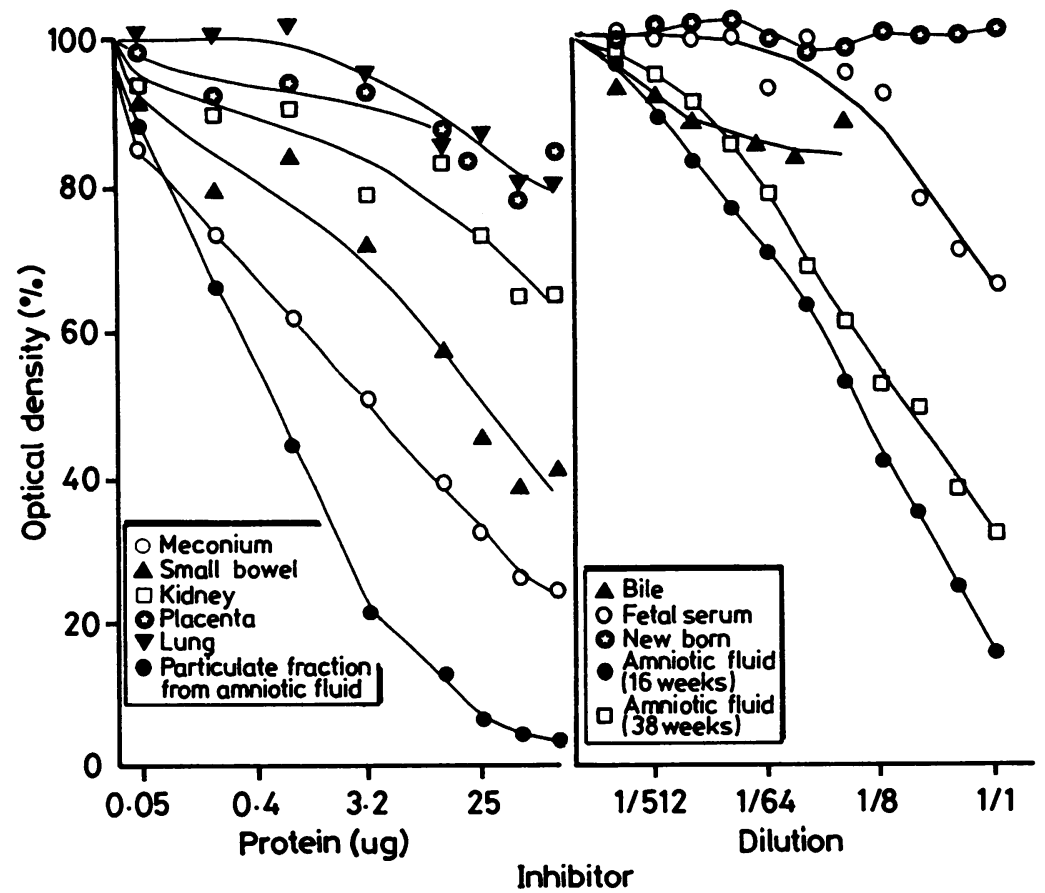

Fig. 7 Inhibition of binding of antisera against particulate fraction from amniotic fuid to particulate fraction in amniotic fuid by different fetal tissues and body fuids. Specimens from 16 week old fetus were used.

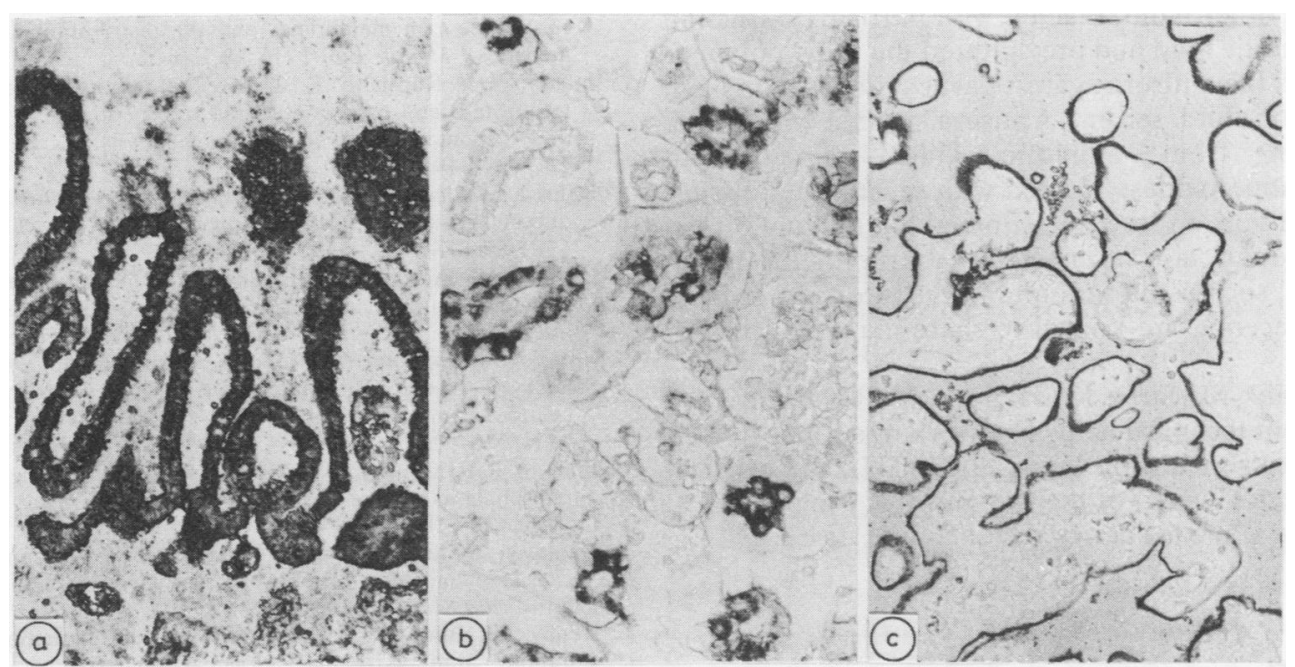

Fig. 8 Indirect immunoperoxidase staining with antisera against particulate fraction from amniotic fuid. (a) Fetal small bowel; (b) kidney; (c) placenta. 
rather than intracellular organelles.

Comparison of the patterns of microvillar enzyme activity in the ultracentrifugation pellets from amniotic fluid, meconium, and fetal tissue homogenates suggests that most of the particulate fraction in amniotic fluid originates from the fetus's gastrointestinal tract. Mulivor et al found that $81 \%$ of the alkaline phosphatase activity in early amniotic fluid was of the intestinal type (phenylalanine sensitive) and the electrophoretic mobility of amniotic fluid alkaline phosphatase resembled that of the fetal intestine. ${ }^{22}$ Potier et al, ${ }^{3}$ on the other hand, compared the disaccharidase activity of amniotic fluid with that reported by Dahlqvist and Lundberg ${ }^{23}$ for fetal gastrointestinal tract and found that the relative specific activities, as related to cellobiose activity, were in the same range.

Clearly, direct comparison of the enzymatic activities in amniotic fluid and whole tissue homogenates, or in simple centrifugation fractions of these specimens, is not accurate. The distribution of the enzymes, for instance, greatly affects the results. Logarithmic differences in the specific activities between the tissue preparations, however, as found here for sucrases, trehalase, and leucine aminopeptidase activities strongly favours the view that the gastrointestinal tract is the source of particulate fraction.

The fetal intestinal origin of particulate fraction in amniotic fluid was also supported by immunological studies. Polyvalent antiserum against this material reacted strongly with extract of meconium and fetal small bowel in immunodiffusion and enzyme immunoassay. Antiserum against early meconium, on the other hand, reacted with particulate fraction in amniotic fluid and precipitated the same polypeptides as the antisera against particulate fraction from amniotic fluid serum. Antisera against particulate fraction from amniotic fluid stained with immunoperoxidase reacted with several fetal tissues in addition to the intestinenal epithelium. This, however, is not surprising as the epithelial membranes, such as those found in the intestine, kidney, and placenta, are known to share many antigens. ${ }^{24}$

We thank Ms Sirpa Kuisma and Ms Ulla Waris for excellent technical help. The work was supported by the Finnish Cultural Foundation (HJ), the Medical Research Council of the Academy of Finland (EL), and the Cancer Society of Finland (HJ, EL).

\section{References}

' Geyer VH, Schneider I. Enzyme in Fruchtwasser. Z Klin Chem Biochem 1970;8:141-4.

${ }^{2}$ Sutcliffe RG, Brock DJ, Robertson JG, Scrimegeour JB, Monaghan JB. Enzymes in amniotic fluid: a study of specific patterns during pregnancy. Journal of Obstetrics and Gynaecology of the British Commonwealth 1972;79:895-901.

${ }^{3}$ Potier ML, Dallaire L, Melancon SB. Occurrance and properties of fetal intestinal glycosidases (disaccharidases) in human amniotic fluid. Biol Neonate 1975;27:141-52.

${ }^{4}$ Palekar AG, Maddaiah V, Collipp PJ, Macri JN. Gammaglutamyl transpeptidase of human amniotic fluid. Am J Obstet Gynecol 1981;141:788-91.

5 Jalanko H, Aula P. Decrease in gamma-glutamyl transpeptidase activity in early amniotic fluid in fetal trisomy 18 syndrome. $\mathrm{Br}$ Med J 1982;284:1593-4.

- Brock DJH, Bedgood D, Hayward C, Carbarns NJ, Gosden C. Amniotic fluid microvillar enzyme activities in the early detection of fetal abnormalities. Prenatal Diagn 1984;4:261-6.

7 Carbarns NJB, Gosden C, Brock DJH. Microvillar peptidase activity in amniotic fluid: possible use in the prenatal diagnosis of cystic fibrosis. Lancet 1983;i:329-31.

${ }^{8}$ Van Diggelen OP, Janse HC, Kleijer WJ. Disaccharidases in amniotic fluid as possible marker for cycstic fibrosis. Lancet 1983;ii: 817.

' Brock DJH, Bedgood D, Hayward C. Prenatal diagnosis of cystic fibrosis by assay of amniotic fluid microvillar enzymes. Hum Genet 1983;65:248-51.

${ }^{10}$ Brock DJH. Amniotic fluid alkaline phosphatase isoenzymes in early prenatal diagnosis of cystic fibrosis. Lancet 1983;ii:9413.

"Jalanko H. Developmental changes in gamma-glutamyl transpeptidase in human amniotic fluid. Oncodev Biol Med 1983;4:253-9.

12 Jalanko H, Ranta T, Lehtonen E, Ruoslahti E. Gamma-glutamyl transpeptidase in human amniotic fluid and in fetal tissues. Clin Chim Acta 1983;134:337-46.

${ }^{13}$ Szasz G. A kinetic photometric method for serum gammaglutamyl transpeptidase. Clin Chem 1969;15:124-36.

14 Jung K, Scholz D. An optimised assay of alanine aminopeptidase activity in urine. Clin Chem 1980;26:1251-4.

is Dahlqvist A. Method for assay of intestinal disaccharidases. And Biochem 1964;7:18-25.

${ }^{16}$ Lowry OH, Rosebrough NJ, Farr AL, Randall JR. Protein measurement with the folin phenol reagent. J Biol Chem 1951;193:265-75.

17 Mircheff AK, Wright EM. Analytical isolation of plasma membranes of intestinal epitherlial cells: identification of $\mathrm{Na}$, K-ATPase rich membranes and the distribution of enzyme activities J Membr Biol 1976;28:309-33.

18 Jalanko HJ, Ruoslahti E. Differential expression of alphafetoprotein and gamma-glutamyl transpeptidase in chemical and spontaneous hepatocarcinogenesis. Cancer Res 1979; 39: 3495-501.

${ }^{19}$ Kahri K, Andersson LC, Vuopio P, Gahmberg CG. Expression of blood group $\mathrm{A}$ antigens in human bone marrow cells. Blood 1981;57:147-51.

${ }^{20}$ Lehtonen E, Asikainen V, Badley RA. Rhabdomyoma. Ultrastructural features and distribution of desmin, muscle type of intermediate filament protein. Acta Pathologica et Microbiologica Scandinavica Section A, Pathology 1982;90:125-9.

21 Salafsky IS, Nadler HL. Intracellular organelles and enzymes in cell-free amniotic fluid. Am J Obstet Gynecol 1971; 111: 1046-52.

${ }^{22}$ Mulivor RA, Mennutti MT, Harris H. Origin of the alkaline phosphatases in amniotic fluid. Am J Obstet Gynecol 1979;135: 77-81.

${ }^{23}$ Dahlqvist A, Linberg T. Development of the intestinal disaccharidase and alkaline phosphatase activities in the human fetus. Clin Sci 1966;30:517-28.

${ }^{24}$ Kenny AJ, Booth AG. Microvilli: their ultrastructure, enzymology and molecular organization. Essays Biochem $1978 ; 14: 1-44$.

Requests for reprints to: Dr Hannu Jalanko, Department of Bacteriology and Immunology, University of Helsinki, Haartmaninkatu 3, 00290 Helsinki 29, Finland. 